\title{
Dial Device
}

National Cancer Institute

\section{Source}

National Cancer Institute. Dial Device. NCI Thesaurus. Code C49919.

Either a circular indicator or a control knob on a device. 